J. Perinat. Med. 15 (1987) 153

\title{
Low Apgar score as a risk factor for respiratory disturbances in the newborn infant
}

\author{
Margareta Wennergren', Marie Krantz ${ }^{2}$, Ola Hjalmarson², and Kirsten Karls- \\ son $^{1}$
}

${ }^{1}$ Department of Obstetrics and Gynecology, Sahlgren's Hospital, and ${ }^{2}$ Department of Pediatrics I, East Hospital, Gothenburg University, Sweden

\section{Introduction}

Since the original observation, made by VIRGINIA APGAR [1], it has been increasingly evident that low Apgar scores imply an elevated risk for development of neonatal respiratory disturbance (RD) $[5,7]$. It is not clear whether a low Apgar score represents a causal factor, or if a low score merely reflects respiratory difficulty present immediately after birth.

In this work our intention was to further analyze by epidemiological methods the association between low Apgar scores and the total spectrum of respiratory diseases in an unselected population. The influence of varying gestational ages and different modes of delivery on the risk factor associated with the Apgar score was studied. Furthermore, we investigated the impact of the various components of the Apgar score on the incidence of respiratory disturbance and the association between the Apgar score and the onset of signs of respiratory disease.

\section{Material and methods}

In a prospective, epidemiologic study, all live born infants of mothers living in Gothenburg, Sweden (about 450,000 inhabitants) were screened over one year for signs of respiratory

\section{Curriculum vitae}

MARgareta WenNerGREN, M.D., graduated from the University of Gothenburg in 1974. She qualified as a specialist in $\mathrm{Ob}$ stetrics and Gynecology and received her medical degree from Gothenburg University in 1985. The subject of her thesis was perinatal riskfactors. Her main fields of interest are

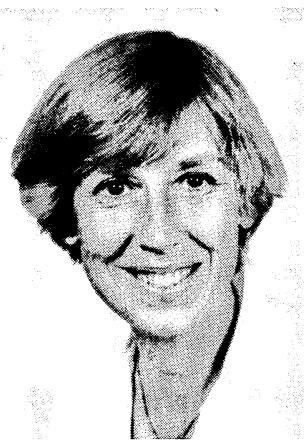

perinatal medicine and particularly, the management of high risk pregnancies.

She is currently working as a lecturer at the Department of Obstetrics and Gynecology at Sahlgren's Hospital, University of Gothenburg.

disease. This unselected population could be obtained since virtually all infants in Gothenburg are born in the two maternity hospitals. The approximate number of deliveries, general standard, equipment, treatment principals and neonatal care are the same in both hospitals. During the year of study, all infants were assessed by Apgar score and screened for development of signs of respiratory disease according to a special routine developed for the study. Apgar scores at one and five minutes after birth 
were assessed by the midwife or obstetrician on duty. Apgar scores of $0-6$ were classified as low, and 7-10 as high.

All infants who developed one of the following signs were considered to have a respiratory disturbance: a breathing frequency of $\geq 60$ / $\min$ or $<30 /$ min for at least three hours, expiratory grunting or retractions of the chest wall, at the age of two hours or later, central cyanosis or apneic spells. All infants fulfilling these criteria were supervised in a neonatal unit and monitored according to a fixed program.

Gestational age was assessed from the number of complete weeks from the onset of the mother's last menstrual period, from ultrasound examinations of the biparietal diameter early in pregnancy and from clinical evaluation of the infants based on external characteristics according to FINNSTRÖM [4]. When maternal data were uncertain or when there was a discrepancy of two weeks or more between maternal and infant data, the results of the latter were used. For the analysis the infants grouped according to gestational age into those up to 32 weeks, between 33 and 36 weeks, and 37 weeks or more.

All information was stored and analyzed using a specially designed computer program, and supplementary data concerning Apgar score distribution in healthy term infants were obtained from the National Birth Registration. For statistical analyses the chi-square test with Yate's modification and the median test were used.

\section{Results}

During the year 4,656 infants were born alive in Gothenburg. Two hundred and forty-one infants were preterm, i. e. $\leq 36$ gestational weeks. There were 528 cesarean sections, which constitutes 11.3 per cent of the deliveries.

Two hundred and sixteen infants ( 4.6 per cent) had low Apgar scores at one minute and 62 (1.3 per cent) at five minutes. In figure 1 , one and five minute Apgar scores are related to

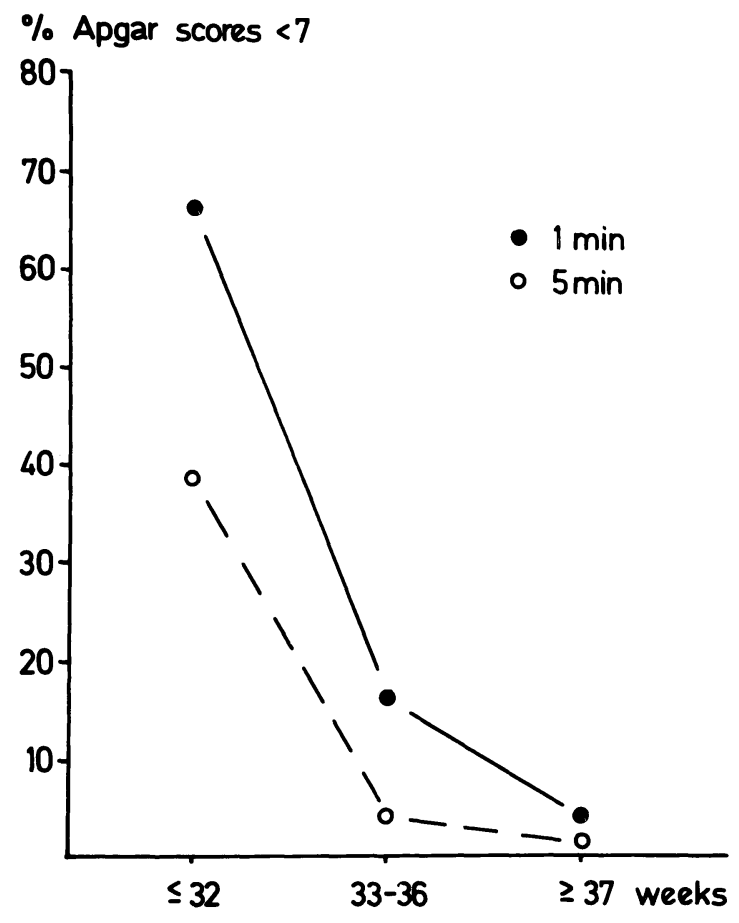

Figure 1. Incidence rate of low Apgar score $(<7)$ at one and five minutes in the population, related to gestational age.

gestational age. The Apgar distribution is closely related to gestational age, with a higher incidence of low Apgar scores at low gestational ages.

Table I gives the incidence rates of RD at high and low Apgar scores at different gestational ages and also related to mode of delivery.

In term infants of vaginal delivery the incidence rate of RD was substantially higher when Apgar score at one minute was low than when Apgar score at one minute was high, 26 per cent versus 3 per cent. The incidence after a low five minute Apgar score was 43 per cent.

Thus in these term infants a low Apgar score at five minutes implied an even greater risk for $\mathrm{RD}$ than a low one minute score. The same pattern was seen after cesarean section but the difference reached statistical significance at five minutes scores only. 
Table I. Incidence rate of respiratory disease at high and low one and five-minute Apgar scores. The results are related to gestational age and route of delivery.

\begin{tabular}{|c|c|c|c|c|c|c|c|}
\hline \multirow{2}{*}{$\begin{array}{l}\text { Route of } \\
\text { delivery }\end{array}$} & \multirow{2}{*}{$\begin{array}{l}\text { Gestational } \\
\text { age (weeks) }\end{array}$} & \multicolumn{3}{|c|}{ Apgar score $1^{\prime}$} & \multicolumn{3}{|c|}{ Apgar score $5^{\prime}$} \\
\hline & & $\geq 7$ & $<7$ & $\mathrm{p}$ & $\geq 7$ & $<7$ & $\mathrm{p}$ \\
\hline & $\leq 32$ & $\begin{array}{c}14 / 14 \\
(100 \%)\end{array}$ & $\begin{array}{l}20 / 20 \\
(100 \%)\end{array}$ & .99 & $\begin{array}{c}20 / 20 \\
(100 \%)\end{array}$ & $\begin{array}{c}12 / 14 \\
(86 \%)\end{array}$ & .32 \\
\hline \multirow[t]{3}{*}{ Vaginal } & $33-36$ & $\begin{array}{l}36 / 117 \\
(31 \%)\end{array}$ & $\begin{array}{c}10 / 14 \\
(71 \%)\end{array}$ & .007 & $\begin{array}{l}42 / 126 \\
(33 \%)\end{array}$ & $\begin{array}{l}4 / 5 \\
(80 \%)\end{array}$ & .096 \\
\hline & $\geq 37$ & $\begin{array}{c}118 / 3861 \\
(3 \%)\end{array}$ & $\begin{array}{r}27 / 102 \\
(26 \%)\end{array}$ & $\ll .001$ & $\begin{array}{c}135 / 3940 \\
(3 \%)\end{array}$ & $\begin{array}{c}10 / 23 \\
(43 \%)\end{array}$ & $\ll .001$ \\
\hline & $\leq 32$ & $\begin{array}{l}2 / 3 \\
(67 \%)\end{array}$ & $\begin{array}{l}9 / 10 \\
(90 \%)\end{array}$ & .96 & $\begin{array}{c}7 / 11 \\
(64 \%)\end{array}$ & $\begin{array}{c}4 / 4 \\
(100 \%)\end{array}$ & .46 \\
\hline \multirow[t]{2}{*}{ Cesarean } & $33-36$ & $\begin{array}{l}21 / 47 \\
(45 \%)\end{array}$ & $\begin{array}{l}9 / 16 \\
(56 \%)\end{array}$ & .61 & $\begin{array}{l}29 / 61 \\
(48 \%)\end{array}$ & $\begin{array}{l}1 / 2 \\
(50 \%)\end{array}$ & .52 \\
\hline & $\geq 37$ & $\begin{array}{l}75 / 397 \\
(19 \%)\end{array}$ & $\begin{array}{c}14 / 55 \\
(25 \%)\end{array}$ & .33 & $\begin{array}{l}81 / 438 \\
(18 \%)\end{array}$ & $\begin{array}{l}8 / 14 \\
(57 \%)\end{array}$ & .0012 \\
\hline
\end{tabular}

In infants born between 33 and 36 weeks of gestation there was a significantly higher incidence of RD after vaginal delivery with low Apgar score at one minute (71 per cent) than when the Apgar score was high (31 per cent). After cesarean section, no significant differences were found, and the picture did not change when emergency and elective cesarean sections were analyzed separately, both in this group and in full term infants. A low Apgar score at five minutes did not imply any additional risk.
Infants below 33 weeks of gestation were few in number, and the incidence rates of RD were generally high. No significant differences between high and low Apgar scores were found.

When only the 195 infants with RD lasting more than 24 hours were considered in the analysis the same pattern was found (table II). A low one minute Apgar score implied an increased incidence rate from 1.5 to 8.8 per cent in the vaginal group and from 4.5 to 20 per

Table II. Incidence rate of respiratory diseases lasting more than 24 hours at high and low one and five-minute Apgar score. The results are related to gestational age and route of delivery.

\begin{tabular}{|c|c|c|c|c|c|c|c|}
\hline \multirow{2}{*}{$\begin{array}{l}\text { Route of } \\
\text { delivery }\end{array}$} & \multirow{2}{*}{$\begin{array}{l}\text { Gestational } \\
\text { age (weeks) }\end{array}$} & \multicolumn{3}{|c|}{ Apgar score $1^{\prime}$} & \multicolumn{3}{|c|}{ Apgar score $5^{\prime}$} \\
\hline & & $\geq 7$ & $<7$ & $\mathrm{p}$ & $\geq 7$ & $<7$ & $\mathrm{p}$ \\
\hline & $\leq 32$ & $\begin{array}{c}8 / 14 \\
(57 \%)\end{array}$ & $\begin{array}{c}8 / 20 \\
(40 \%)\end{array}$ & .52 & $\begin{array}{l}11 / 20 \\
(55 \%)\end{array}$ & $\begin{array}{c}5 / 14 \\
(36 \%)\end{array}$ & .45 \\
\hline \multirow[t]{3}{*}{ Vaginal } & $33-36$ & $\begin{array}{l}20 / 117 \\
(17 \%)\end{array}$ & $\begin{array}{c}7 / 14 \\
(50 \%)\end{array}$ & .012 & $\begin{array}{l}24 / 126 \\
(19 \%)\end{array}$ & $\begin{array}{c}3 / 5 \\
(60 \%)\end{array}$ & .098 \\
\hline & $\geq 37$ & $\begin{array}{c}56 / 3861 \\
(1 \%)\end{array}$ & $\begin{array}{l}9 / 102 \\
(9 \%)\end{array}$ & $\ll .001$ & $\begin{array}{c}64 / 3940 \\
(2 \%)\end{array}$ & $\begin{array}{c}6 / 23 \\
(26 \%)\end{array}$ & $\ll .001$ \\
\hline & $\leq 32$ & $\begin{array}{c}2 / 3 \\
(67 \%)\end{array}$ & $\begin{array}{c}7 / 10 \\
(70 \%)\end{array}$ & .71 & $\begin{array}{c}6 / 9 \\
(67 \%)\end{array}$ & $\begin{array}{c}3 / 4 \\
(75 \%)\end{array}$ & .65 \\
\hline \multirow[t]{2}{*}{ Cesarean } & $33-36$ & $\begin{array}{c}9 / 47 \\
(19 \%)\end{array}$ & $\begin{array}{c}4 / 16 \\
(25 \%)\end{array}$ & .89 & $\begin{array}{l}12 / 61 \\
(20 \%)\end{array}$ & $\begin{array}{c}1 / 2 \\
(50 \%)\end{array}$ & .88 \\
\hline & $\geq 37$ & $\begin{array}{c}18 / 397 \\
(5 \%)\end{array}$ & $\begin{array}{l}11 / 55 \\
(20 \%)\end{array}$ & $<.001$ & $\begin{array}{c}21 / 438 \\
(5 \%)\end{array}$ & $\begin{array}{c}3 / 14 \\
(21 \%)\end{array}$ & .033 \\
\hline
\end{tabular}


cent in the cesarean group. A low five minute score further increased the incidence rate in both groups, to 26 per cent after vaginal and 21 per cent after cesarean delivery.

Meperidine (Pethidine), given to $30 \%$ of mothers of preterm infants and $20 \%$ of mothers of full term infants was not a confounder as the incidence rate of $\mathrm{RD}$ was the same whether meperidine was given or not, in preterm as well as full term infants.

In order to elucidate whether onset of signs of $\mathrm{RD}$ was more rapid in infants with low Apgar scores compared to those with high scores the interval from birth to the first appearance of signs of RD was noted (table III). There were no statistically significant differences between the groups with the exception of infants of $33-36$ weeks born by cesarean section. In this group newborns with high Apgar scores had a significantly later onset of signs of RD (0.9 versus 0.3 hours). In the majority of the cases, signs of RD did not appear immediately after birth but from 0.5 up to 4 hours later. The signs appeared somewhat earlier in preterm infants than in term infants. No differences attributable to mode of delivery were found.

To evaluate whether any particular component in the Apgar score was more predictive of respiratory disease than the others, all infants with low one minute Apgar scores were analyzed. The same distribution of the components of the score was seen in all groups ( $\mathrm{x}^{2}$-test; n. s.) (figure 2). The respiratory effort was no more affected than the other signs in the Apgar score. Infants $\leq 32$ weeks are not included in the figure since there were few such infants in each category.

\section{Discussion}

It has been demonstrated that the Apgar score is not a reliable measure of intrauterine asphyxia [9]. Both this study and previous ones have shown that a low Apgar score is a remarkably powerful risk factor for neonatal respiratory disturbance in full term infants. Consequently, this power should be based on other mechanisms than fetal asphyxia. The great

Table III. Onset of respiratory disease (RD) in infants with high and low one minute Apgar scores and after different routes of delivery. Time for onset of respiratory signs was missing for some infants and thus the number in each category is not always the same as that given in tables I and II.

\begin{tabular}{|c|c|c|c|c|c|c|}
\hline \multirow{3}{*}{$\begin{array}{l}\text { Route of } \\
\text { delivery }\end{array}$} & \multirow{3}{*}{$\begin{array}{l}\text { Gestational } \\
\text { age (weeks) }\end{array}$} & \multicolumn{5}{|c|}{ Apgar score at one minute } \\
\hline & & \multicolumn{2}{|l|}{$\geq 7$} & \multicolumn{3}{|l|}{$<7$} \\
\hline & & $\begin{array}{l}\text { Infants } \\
\text { with RD } \\
\text { (N) }\end{array}$ & $\begin{array}{l}\text { Median } \\
\text { and ranges } \\
\text { (hours) }\end{array}$ & $\begin{array}{l}\text { Infants } \\
\text { with RD } \\
\text { (N) }\end{array}$ & $\begin{array}{l}\text { Median } \\
\text { and range } \\
\text { (hours) }\end{array}$ & $\mathrm{p}$ \\
\hline & $\leq 32$ & 12 & $\begin{array}{l}0.4 \\
0-1\end{array}$ & 17 & $\begin{array}{l}0.3 \\
0-14\end{array}$ & .46 \\
\hline \multirow[t]{3}{*}{ Vaginal } & $33-36$ & 36 & $\begin{array}{l}0.9 \\
0-13\end{array}$ & 9 & $\begin{array}{l}0.6 \\
0-8\end{array}$ & .40 \\
\hline & $\geq 37$ & 112 & $\begin{array}{l}2.0 \\
0-86\end{array}$ & 24 & $\begin{array}{l}1.3 \\
0-26\end{array}$ & .16 \\
\hline & $\leq 32$ & 2 & $\begin{array}{l}0.3 \\
0.1-0.5\end{array}$ & 8 & $\begin{array}{l}0.6 \\
0-2.4\end{array}$ & .44 \\
\hline \multirow[t]{2}{*}{ Cesarean } & $33-36$ & 21 & $\begin{array}{l}0.9 \\
0-8\end{array}$ & 9 & $\begin{array}{l}0.3 \\
0-2\end{array}$ & .037 \\
\hline & $\geq 37$ & 68 & $\begin{array}{l}1.0 \\
0-12\end{array}$ & 13 & $\begin{array}{l}0.4 \\
0-6\end{array}$ & .81 \\
\hline
\end{tabular}



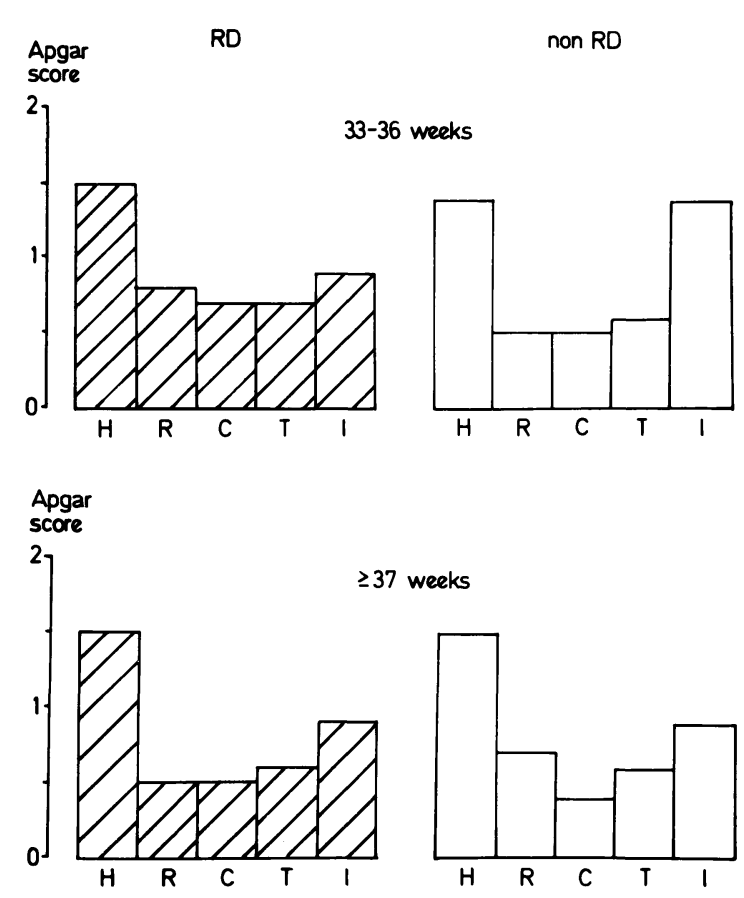

Figure 2. Mean rates of the components of Apgar score in infants with and without respiratory disturbance (RD). Results from all infants between 33 and 36 weeks of gestation and above 37 weeks with one minute Apgar score $<7$ are shown.

$\mathrm{H}=$ heart rate, $\mathrm{R}=$ respiration, $\mathrm{C}=$ color, $\mathrm{T}=$ muscle tone, $\mathrm{I}=$ reflex irritability.

majority of the infants with respiratory signs in this study had disturbances of short duration with or without pathological chest films. They fit diagnostic criteria for 'transient tachypnea' [2] or 'pulmonary maladaptation'/'mild respiratory disease' [7].

As expected we found that preterm infants in general run considerably higher risks for RD than term infants do. On the other hand the importance of a low Apgar score as an additional risk factor is reduced or becomes negligible when gestational age is low. The effect of a low Apgar score was less pronounced after cesarean section than after vaginal delivery.

It is generally believed that alveolar or interstitial edema is the dominating phenomenon in the main neonatal lung disorders. In animal studies it has been well demonstrated that catecholamines play an important part in eliminating fluid from the lungs before and at term birth [10]. In animals this mechanism cannot be elicited before term [10]. If this is also true in humans it may offer one explanation of the high incidence rate of RD among preterm infants. It has also been shown that mildly acidotic, term infants with low Apgar scores have lower levels of catecholamines in cord blood than infants with high scores, suggesting that the Apgar score, to some extent, may reflect sympathoadrenal activity at birth [8].

These observations may offer an explanation for our results. The risk factors for RD, identified in the analysis, low gestational age and low Apgar scores, may be associated with a failure to release or respond to catecholamines at birth and hence to eliminate lung fluid effectively. Such a common mechanism may also explain the interdependence of the risk factors, and why the risk factor associated with low Apgar score is most powerful in full term infants. The reduced power of this factor after cesarean section is also compatible with the hypothesis that abdominal delivery per se disposes to neonatal lung hyperhydration leading to respiratory disease.

According to the hypothesis presented, a low Apgar score is a marker of a disturbed adaption process also associated with lung hyperhydration. Other data suggest that low vitality immediately after birth may play a more direct part in the pathogenesis of neonatal lung disease. Lung expansion at the first breaths after birth has been shown to be important for the establishment of appropriate lung circulation, and also for lung surfactant release [6]. Consequently, failure to expand the lungs effectively after birth may lead to interstitial edema formation due to high surface tension and to partial atelectasis. Boon et al. [3] also found the formation of functional residual capacity after birth to be delayed in newborn infants with low Apgar scores. This means that anything affecting the fetus and the newborn severely enough to cause low vitality at birth, and thus a low Apgar 
score, such as cerebral birth trauma, anoxia or anesthetic agents, may also initiate a disturbance of the lung adaption process leading to respiratory difficulty. In this context it is of interest to note that in the group with low Apgar scores the distribution of the various components of the score was the same in infants who developed RD and those who did not. One might speculate that if RD was only an effect of lung water retention, the respiratory component of the score would have been lower among infants who developed RD.

\section{Summary}

The value of the Apgar score as a risk factor for all neonatal respiratory disturbances (RD) was evaluated in a prospective study of an unselected population. All liveborn infants $(n=4656)$ of mothers living in Gothenburg were screened over one year for signs of respiratory disease. This unselected population could be obtained since virtually all infants in Gothenburg are born in two maternity hospitals, with similar treatment principles, the same equipment standard and neonatal care. A low one minute Apgar score $(<7)$ was found to be a powerful risk factor for RD in full term newborns and infants of 33-36 weeks gestation provided that the delivery had been vaginal. In these infants a low Apgar score at five minutes further increased the risk of RD. In immature infants $<32$ weeks and after cesarean section in all gestational ages a low Apgar score did not mean any additional risk of RD (table I). The respiratory component in the Apgar score was not more predictive
Although most of our data may be explained by the catecholamine hypothesis, there is no doubt that insufficient initial lung expansion may play an important part as an alternative mechanism in explaining the relationship between low Apgar scores and neonatal RD. We could exclude RD after a low Apgar score being merely a prolongation of the initial respiratory difficulty. In the infants with RD, regardless of Apgar score level, there was normally an interval free from respiratory signs after birth. Why this period exists remains to be explained.

of RD than any of the others (figure 2). In most infants with $\mathrm{RD}$, irrespective of Apgar score, there was a few hours interval free from respiratory signs after birth (table III).

It has been well shown in other studies that Apgar score is not a reliable index of intrauterine or birth asphyxia. Nevertheless the one-minute score is a powerful predictor of neonatal respiratory difficulties. One explanation might be that Apgar score is correlated with sympathoadrenal activity at birth. Another might be that the vitality in the period immediately after birth - reflected by the Apgar score - is crucial for the ability of the infant to expand the lungs effectively after birth. This may affect the respiratory adaptation in the postnatal period by hampering the ability to eliminate lung water, by suppressing surfactant release or by other mechanisms.

Keywords: Apgar score, neonatal asphyxia, newborn infant, respiratory disorders.

\section{Zusammenfassung}

\section{Niedriger Apgar-Score als Risikofaktor für pulmonale Komplikationen bei Neugeborenen}

In einer prospektiven Studie wurde in einem unselektierten Kollektiv die Aussagekraft des Apgar-Scores als Risikofaktor für respiratorische Störungen beim Neugeborenen geprüft. In einem Zeitraum von einem Jahr wurde bei allen lebendgeborenen Kindern in Gothenburg $(n=4656)$ ein Screening durchgeführt, um respiratorische Störungen zu erfassen. Die Zusammenstellung dieses großen Kollektivs war deshalb möglich, weil alle Kinder in Gothenburg in zwei großen Entbindungskliniken geboren werden, die mit vergleichbaren Behandlungsprinzipien sowie ähnlicher technischer Ausrüstung und Neonatologie arbeiten. Bei Reifgeborenen und bei Kindern aus der 33.-36. Gestationswoche, soweit sie vaginal entbunden wurden, war ein niedriger ApgarWert 1 Minute post partum $(<7)$ ein sehr aussagekräftiger Parameter im Hinblick auf die Entwicklung pulmonaler Komplikationen. Bei diesen Kindern war das Risiko bei einem niedrigen Apgar-Wert nach 5 Minuten nochmals erhöht. Bei unreifen Kindern $<32$ Wochen und nach Sectiones unabhängig vom Schwangerschaftsalter bedeutete ein niedriger Apgar-Score kein erhöhtes Risiko (Tabelle I). Die Beurteilung der Atmung im Apgar-Score war nicht aussagekräftiger als andere Parameter im Hinblick auf die Entwicklung respiratorischer Störungen (Abb. 2). Bei den meisten Kindern mit pulmonalen Komplikationen war, unabhängig vom ApgarScore, zunächst ein Intervall von wenigen Stunden, in dem die Atmung ungestört war (Tabelle III). 
In anderen Untersuchungen wurde nachgewiesen, daß der Apgar-Score keine zuverlässige Aussage über intrauterine oder subpartuale Asphyxien liefert. Trotzdem ist der 1-Minuten-Wert ein wichtiger Hinweis, was die Entwicklung respiratorischer Störungen beim Neugeborenen betrifft. Eine mögliche Erklärung ist, daß der Apgar-Score mit der sympathoadrenergen Aktivität zum Zeitpunkt der Geburt korreliert. Darüber hinaus ist die
Vitalität unmittelbar post partum, die sich im ApgarScore ausdrückt, entscheidend für die Fähigkeit des Neugeborenen zur effektiven Lungenexpansion. Ist die Vitalität beeinträchtigt, wird die respiratorische Adaptation in der Postnatalperiode durch mangelhafte Eliminierung von Lungenwasser, Unterdrückung der Surfactant-Ausschüttung oder andere Mechanismen gestört sein.

Schlüsselwörter: Apgar Score, neonatale Asphyxie, Neugeborenes, respiratorische Störungen.

\section{Résumé}

Le score d'Apgar bas comme facteur de risque de troubles respiratoires chez le nouveau-né

On a évalué dans une étude prospective sur une population non sélectionnée la valeur du score d'Apgar comme facteur de risque de l'ensemble des troubles respiratoires (TR). Tous les enfants nés vivants $(n=4656)$ de mères habitant in Gothenburg ont été examinés pendant un an à la recherche de signes d'affections respiratoires. On a pu obtenir cette population non sélectionnée car pratiquement tous les enfants de Gothenburg sont nés dans deux maternités hospitalières qui appliquent des principes thérapeutiques semblables, qui possèdent les mêmes équipements standards et pratiquent les mêmes soins néonataux. On a mis en évidence le fait qu'un score d'Apgar bas à une minute $(<7)$ est un excellent facteur de risque de TR chez les nouveaux-nés à terme et chez les enfants de 33-36 semaines gestationnelles à condition que l'accouchement ait été effectué par voie basse. Chez ces enfants un score d'Apgar bas à cinq minutes augmente encore le risque de TR. Chez les enfants prématurés de moins de 32 semaines et nés par césarienne quel que soit l'âge gestationnel, un score
d'Apgar bas n'apporte pas de risque supplémentaire de TR (tableau I). La composante respiratoire du score d'Apgar n'est pas plus prédictive de TR que les autres composantes (figure 2). Chez la plupart des enfants avec TR, quel que soit le score d'Apgar, il existe un intervalle libre de quelques heures après la naissance sans signes respiratoires (tableau III).

D'autres études ont bien montré que le score d'Apgar n'est pas un indice fiable d'asphyxie intra-utérine ou à la naissance. Néanmoins, le score d'Apgar à une minute est un excellent moyen de prévoir des difficultés respiratoires néonatales. Une explication de ce fait pourrait être que le score d'Apgar est correlé à l'activité sympathique à la naissance. Une autre explication pourrait être que la vitalité dans la période qui suit immédiatement la naissance, reflétée par le score d'Apgar, est cruciale pour la capacité d'expansion efficace des poumons après la naissance chez les enfants. Cela pourrait affecter l'adaptation respiratoire dans la période postnatale en entravant la capacité d'éliminer le liquide pulmonaire, en supprimant la libération de surfactant ou par d'autres mécanismes.

Mots-clés: Asphyxie néonatale, nouveau-né, score d'Apgar, trouble respiratoire.

Acknowledgements: This research was supported by the Swedish Medical Research Council (Project No 05 703) and by the Gothenburg Medical Society (Gbg L 199/84). We thank MARGARETA RYDÉN for excellent typing of the manuscript.

\section{References}

[1] APGaR V, LS JAMES: Further observations on the newborn scoring system. Am J Dis Child 104 (1962) 419

[2] Avery ME, OB Gatewood, G Brumley: Transient tachypnea of the newborn. Am J Dis Child 111 (1966) 380

[3] Boon AW, AD MiLner, IE HopkIN: Lung expansion, tidal exchange, and formation of the functional residual capacity during resuscitation of asphyxiated neonates. J Pediatr 95 (1979) 1031
[4] FinNSTRÖM O: Studies on maturity in newborn infants. IX. Further observation on the use of external characteristics in estimating gestational age. Acta Paediatr Scand 66 (1977) 601

[5] Gross TL, RJ Sokol, M Wilson, MS Kwong, PM KUHNERT: Transient tachypnea of the newborn: The relationship to preterm delivery and significant neonatal morbidity. Am J Obstet Gynecol 146 (1983) 236 
[6] Hildebran JN, J Goerke, JA Clements: Surfactant release in excised rat lung is stimulated by air inflation. J Appl Physiol 51 (1981) 905

[7] HJalmarson O: Epidemiology and classification of acute neonatal respiratory disorders. Acta Paediatr Scand 70 (1980) 773

[8] LAGERCRANTz H: Asphyxia and the Apgar score. Lancet 1 (1982) 966

[9] Sykes GS, PM Molloy, P Johnson et al: Do Apgar score indicate asphyxia? Lancet 1 (1982) 494
[10] WaLters DV, RE OlVER: The role of catecholamines in lung liquid absorption at birth. Pediatr Res 12 (1978) 239

Received October 26, 1985. Revised July 10, 1986. Accepted August 13, 1986.

Dr. Margareta Wennergren

Department of Obstetrics and Gynecology

Sahlgren's Hospital

S-413 45 Gothenburg

Sweden 